\title{
Pembuatan Aplikasi Prediksi Harga Saham Berbasis Web Menggunakan Metode Holt's: Studi Kasus Di PT Bank Central Asia Tbk
}

\author{
Nabihah Hanun Atikah, Arif Djunaidy, dan Faizal Mahananto \\ Departemen Sistem Informasi, Fakultas Tekonologi Informasi, Institut Teknologi Sepuluh Nopember (ITS) \\ e-mail: adjunaidy@gmail.com
}

\begin{abstract}
Abstrak-Salah satu indeks harga saham yang banyak diminati investor di Indonesia adalah indeks saham LQ45. Pada indeks saham LQ45 terdiri atas 45 perusahaan besar dan dapat dijadikan prospek bisnis yang bagus bagi para investor. Salah satunya adalah PT Bank Central Asia Tbk. Data deret waktu yang digunakan dalam penelitian ini adalah data historis harga penutupan saham periode harian PT Bank Central Asia Tbk selama 4 tahun antara tahun 2013 hingga 2016. Pergerakan harga penutupan saham tersebut cenderung mengalami peningkatan dan diindikasikan bahwa pola datanya memiliki sifat kecenderungan (trend) meningkat. Sehingga pada eksperimen ini menggunakan metode deret waktu double exponential smoothing (DES) Holt's, karena metode pemulusan ini dapat mengatasi data deret waktu yang memiliki pola trend. Oleh karena itu, perlu dibuat sebuah aplikasi prediksi pergerakan harga saham berbasis web yang nantinya dapat digunakan oleh investor dan pelaku pasar modal sebagai pertimbangan dalam melakukan investasi dengan mudah. Berdasarkan penelitian yang telah dilakukan, diperoleh hasil nilai MAPE terkecil yaitu $0.823 \%$ dari model terbaik yang dibangun berdasarkan eksperimen. Model terbaik dihasilkan dari pembagian data training $\mathbf{7 0 \%}$, data validasi $20 \%$ dan data testing $10 \%$.
\end{abstract}

Kata kunci-Aplikasi prediksi, LQ45, BCA, prediksi, Holt's, historis, harga saham.

\section{I. PENDAHULUAN}

$\mathrm{P}$ ASAR Modal merupakan sistem keuangan yang terorganisasi terdiri dari bank komersial, lembaga perantara di bidang keuangan dan seluruh surat-surat berharga yang beredar. Salah satu manfaat dari pasar modal adalah menciptakan kesempatan kepada masyarakat untuk berpartisipasi dalam kegiatan perekonomian khususnya dalam berinvestasi [1]. Salah satu asset untuk investasi adalah saham. Saham merupakan surat berharga yang menunjukkan kepemilikan atau penyertaan pasar modal investor dalam suatu perusahaan [2]. Pendapatan yang didapat dari pemegang saham, tergantung dari perusahaan yang menerbitkan saham (emiten). Jika emiten mampu menghasilkan keuntungan yang besar maka keuntungan yang didapatkan oleh pemegang saham juga akan besar. Semakin tinggi return yang ditawarkan maka semakin tinggi pula risiko yang harus ditanggung investor [3]. Oleh karena itu perlu dilakukan prediksi harga saham berdasarkan data historis di masa lalu.

Salah satu indeks harga saham yang banyak dilirik investor adalah indeks saham LQ45 pada bursa saham Indonesia. Pada indeks saham LQ45 terdiri atas 45 perusahaan-perusahaan besar dan dapat dijadikan prospek bisnis yang bagus bagi para investor [4]. Salah satunya adalah Bank BCA. Berdasarkan data statistik bursa efek Indonesia 2015, dapat diketahui bahwa baik dari segi kapitalisasi pasar maupun nilai transaksi perdagangan saham, saham sektor keuangan berada di posisi pertama. Tak heran jika saham sektor keuangan saat ini masih sangat digemari investor untuk terus diperdagangkan setiap harinya di lantai bursa. Apalagi ada beberapa saham sektor keuangan yang memiliki kapitalisasi pasar dan likuiditas yang tinggi, seperti saham perbankan. Besarnya nilai transaksi saham sektor keuangan juga didominasi oleh empat saham besar perbankan, yaitu saham PT Bank Central Asia Tbk (BBCA), PT Bank Rakyat Indonesia Tbk (BBRI), PT Bank Mandiri Tbk (BMRI) dan PT Bank Negara Indonesia Tbk (BBNI) [5].

Dari segi aspek bisnis, investasi saham memiliki pertumbuhan yang paling fantastis tetapi tentu ini tidak berlaku untuk semua saham. Berdasarkan laporan keuangan perusahaan yang memiliki pertumbuhan paling fantastis adalah Bank BCA dan Astra International. Dimana kedua perusahaan tersebut paling dikenal masyarakat dan dipercaya memiliki aspek fundamental yang bagus dan sehat yang memiliki pertumbuhan sekitar 25-30\% per tahun [6]. Hal ini menunjukkan prospek bisnis yang bagus untuk para investor maupun pelaku bisnis saham di Indonesia untuk melakukan investasi.

Peramalan merupakan prediksi nilai-nilai sebuah variabel berdasarkan kepada nilai yang diketahui dari variabel tersebut atau variabel lain yang berhubungan. Pada metode peramalan kategori kuantitatif, khususnya model deret waktu (time series) dikenal beberapa metode pemulusan yaitu dengan perataan (average) dan pemulusan eksponensial. Data yang memiliki trend didefinisikan sebagai deret waktu yang berisi komponen jangka panjang yang mewakili pertumbuhan atau penurunan dalam deret, dan nilai rata-ratanya berubah menaik atau menurun disepanjang periode waktu [7]. Metode double exponential smoothing dari Holt's merupakan salah satu pemulusan eksponensial yang disesuaikan untuk kondisi data amatan yang mengandung trend [7].

Data deret waktu yang digunakan dalam penelitian ini adalah harga penutupan saham periode harian PT Bank Central Asia Tbk selama 4 tahun antara tahun 2013 hingga 2016. Pergerakan harga penutupan saham tersebut cenderung 
mengalami peningkatan secara terus menerus dan diindikasikan bahwa pola datanya memiliki sifat kecenderungan (trend). Sehingga pada penelitian ini menggunakan metode time series double exponential smoothing dari Holt's, karena metode pemulusan ini dapat mengatasi data deret waktu yang memiliki pola trend.

Berdasarkan pertimbangan yang sudah dipaparkan sebelumnya, maka pada eksperimen ini, penulis mengambil studi kasus peramalan harga saham menggunakan metode Holt's pada Bank Central Asia (BCA). Adapun keluaran yang akan dihasilkan dari eksperimen ini adalah sebuah aplikasi berbasis web untuk memprediksi harga saham. Dari aplikasi prediksi harga saham ini diharapkan akan membantu investor maupun pelaku pasar modal dalam mengambil keputusan investasi saham di Bursa Efek Indonesia.

\section{METODOLOGI}

Tahapan pelaksanaan penelitian yang akan dilakukan dapat dilihat pada Gambar 1.

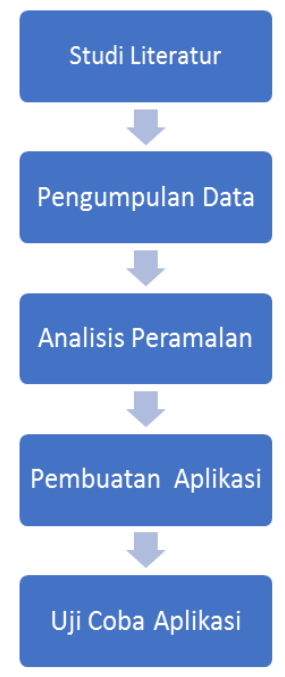

Gambar 1. Tahapan Pelaksanaan Penelitian

\section{A. Studi Literatur}

Studi literatur didapatkan dari pengumpulan referensi, diantaranya dari buku, penelitian sebelumnya, dan dokumen yang terkait double exponential smoothing holt's, dan PHP untuk mendapatkan pemahaman tentang studi yang diperlukan. Tahap studi literatur ini dilakukan dari awal sampai akhir penelitian.

\section{B. Pengumpulan Data}

Pada tahap ini dilakukan pengumpulan data yang dibutuhkan dalam eksperimen. Proses pengumpulan data dilakukan dengan mengunduh data historis harga saham PT Bank Central Asia dengan kode saham BBCA.JK dengan periode harian selama empat tahun dari tanggal 31 Desember 2012 sampai dengan 28 April 2017 pada website yahoo finance. Jenis harga saham yang digunakan adalah harga saham penutupan (close price) yang merupakan harga saham terakhir atau harga pentupan pindah hari. Jumlah total data yang digunakan adalah 1120 data dan tidak termasuk hari libur.

\section{Analisis Peramalan}

Pada proses ini, terdapat tiga subproses yang dilakukan yaitu pembuatan model peramalan, pelatihan model peramalan, dan pengujian model peramalan. Metode peramalan yang digunakan telah ditentukan pada proses studi literature dan menjadi masukan pada proses ini.

\section{1) Pembuatan Model Peramalan}

Pada tahap ini yang dilakukan yaitu membuat model peramalan yang didasarkan dari studi yang telah dilakukan dengan menggunakan metode peramalan double exponential smoothing holt's. Model peramalan dibuat untuk digunakan pada proses selanjutnya. Model peramalan double exponential smoothing Holt's dilakukan pada MS. Excel dengan memasukkan rumus metode Holt's.

\section{2) Pelatihan Model Peramalan}

Pada tahap ini melakukan pelatihan model peramalan dengan data historis yang dimiliki (data pelatihan) hingga model menjadi model yang tepat dilihat dari akurasi model. Jumlah data historis yang digunakan untuk pelatihan model metode double exponential smoothing digunakan sebagai percobaan komposisi data, yang nantinya akan dipilih komposisi data yang menghasilkan nilai kesalahan MAPE terkecil. Dan juga dari proses pelatihan model dihasilkan nilai alpha dan beta yang optimal dari 81 percobaan. Yang nantinya nilai alpha dan beta yang optimal tersebut digunakan pada data validasi dan data testing.

\section{3) Pengujian Model Peramalan}

Pada tahap ini model yang diperoleh dari tahap pelatihan dilakukan validasi dan diambil yang terbaik dari hasil validasi. Kemudian model yang terbaik dikonfirmasi menggunakan data pengujian. Sehingga tahapan akhir pengujian model peramalan hanya untuk mengkonfirmasi model terbaik yang diperoleh dari pelatihan dan validasi memang benar-benar bagus. Jumlah data historis yang digunakan untuk pengujian model metode double exponential smoothing holts digunakan sebagai percobaan komposisi data, yang nantinya akan dipilih komposisi data yang menghasilkan nilai kesalahan MAPE terkecil.

\section{Pembuatan Aplikasi}

Pada tahap ini merupakan tahap pengerjaan desain aplikasi dan implementasi aplikasi. Desain aplikasi peramalan terdiri dari desain use case, desain sequence, desain antar-muka, dan desain data aplikasi peramalan yang akan dibangun. Dan implementasi aplikasi terdiri dari pembuatan basis data dan kode program.

\section{1) Desain Aplikasi}

\section{a) Desain Use Case}

Pada tahap ini dilakukan pembuatan diagram use case yang digunakan untuk memodelkan layanan yang disediakan oleh aplikasi. Dan juga membuat deskripsi use 
case untuk penjelasan mengenai masing-masing fungsionalitas aplikasi. Gambar 2 merupakan use case model untuk aplikasi peramalan harga saham berbasis web. Adapun program aplikasi yang digunakan pada tahap ini adalah Enterprise Architect.

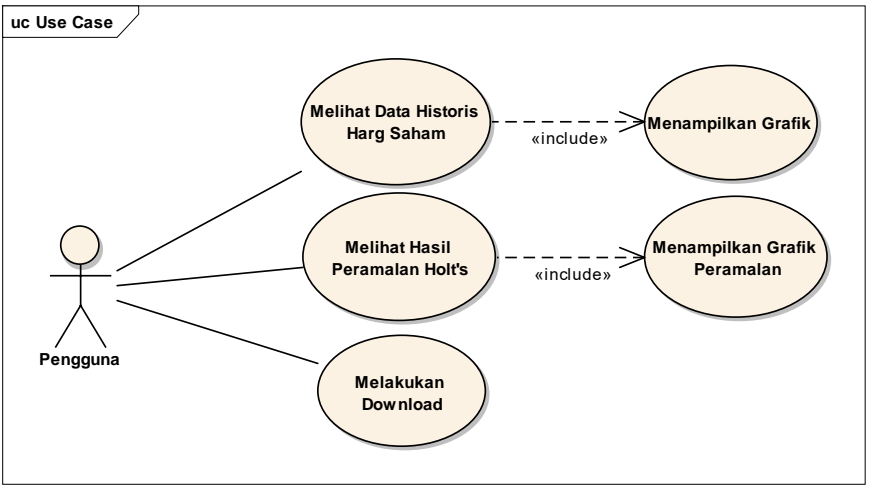

Gambar 2. Use Case Diagram

\section{UC-01: Melihat Data Historis Harga Saham}

UC-01 adalah kebutuhan (fungsi) pengguna untuk dapat melihat data historis saham sesuai dengan periode yang dipilih pengguna. Use case dimulai dari pengguna memilih periode saham yang diinginkan, kemudian aplikasi menampilkan data aktual harga saham dan hasil peramalan sesuai dengan periode yang dipilih.

\section{UC-02: Melihat hasil peramalan metode Holt's}

UC-02 adalah kebutuhan (fungsi) pengguna untuk dapat melihat hasil peramalan dengan metode holt's. Use case dimulai dari pengguna telah mengupload file .csv yang berisi data nomor, tanggal, dan harga saham aktual atau pengguna menginputkan tanggal, data aktual, dan jumlah waktu peramalan yang diinginkan. Aplikasi akan menampilkan hasil peramalan sesuai dengan jumlah waktu peramalan yang diinputkan.

\section{UC-03: Melakukan download}

UC-03 adalah kebutuhan (fungsi) pengguna untuk dapat mendownload hasil peramalan dalam bentuk csv, pdf, atau word. Use case dimulai dari pengguna telah melakukan peramalan kemudian pengguna mengklik tombol csv, pdf, atau word.

\section{b) Desain Sequence}

Pada tahap ini yang dilakukan adalah membuat sequence diagram. Sequence diagram dibuat sesuai dengan scenario/deskripsi dari use case diagram yang telah dibuat sebelumnya yang menitikberatkan pada urutan kronologi peristiwa. Adapun program aplikasi yang digunakan pada tahap ini adalah Enterprise Architect.

\section{c) Desain Antar-muka}

Pada tahap ini membuat desain tampilan halaman aplikasi yang akan dibangun. Desain antar-muka aplikasi dibuat sesuai dengan hasil analisis kebutuhan aplikasi yang telah didefinisikan sebelumnya yang mengacu pada deskripsi use case dan sequence diagram yang telah dihasilkan.

\section{d) Desain Data}

Desain data dilakukan untuk mengetahui data apa saja yang diperlukan sebagai masukan dari aplikasi yang akan dibuat. Pada pelaksanaan tahap ini digunakan tools yaitu xampp dan phpMyadmin.

\section{2) Implementasi Aplikasi}

Pada tahap ini dilakukan dengan pembuatan kode aplikasi menggunakan bahasa pemrograman $P h p$ dengan MySQL sebagai manajemen basis datanya. Adapun pengembangan aplikasi ini akan menggunakan software aplikasi Sublime Text 3.0.

\section{E. Uji Coba Aplikasi}

Pada tahap ini akan dilakukan uji coba terhadap aplikasi yang telah dibuat pada bagian sebelumnya. Adapun jenis uji coba aplikasi mengacu kepada metode pengujian black-box yaitu dilakukan dengan menjalankan fungsional aplikasi dan melakukan evaluasi terhadap aplikasi.

\section{HASIL DAN PEMBAHASAN}

Tahapan dalam melakukan peramalan holt's, yaitu mencari nilai alpha dan beta yang optimal, memilih model terbaik dengan melakukan percobaan 3 komposisi data, kemudian melakukan pengujian data, dan melakukan pengujian model.

\section{A. Mencari nilai alpha dan beta yang optimal}

Pada tahap ini mencari nilai alpha dan beta yang optimal dengan melakukan percobaan 81 kombinasi nilai alpha dan beta menggunakan data pelatihan, kemudian mencari nilai MAPE yang paling kecil. Berdasarkan percobaan yang telah dilakukan, didapat nilai MAPE terkecil $1,198 \%$ terdapat pada saat nilai $\alpha=0,9$ dan $\beta=0,1$. Maka pada eksperimen ini dan pada aplikasi web menggunakan nilai alpha 0,9 dan nilai beta 0,1 .

\section{B. Memilih model terbaik dengan percobaan 3 komposisi data}

Setelah menentukan nilai alpha dan beta yang optimal, pada tahap ini dilakukan percobaan tiga komposisi data yang dibandingkan, yaitu $60 \%$ data pelatihan, $25 \%$ data validasi, dan $15 \%$ data pengujian atau 672 buah data harian sebagai data pelatihan, 280 buah data harian sebagai data validasi, dan 168 buah data harian sebagai data pengujian, $70 \%$ data pelatihan, $20 \%$ data validasi, dan $10 \%$ data pengujian atau 784 buah data harian sebagai data pelatihan, 224 buah data harian sebagai data validasi, dan 112 buah data harian sebagai data pengujian, serta $80 \%$ data pelatihan, $15 \%$ data validasi, dan 5\% data pengujian atau 896 buah data harian sebagai data pelatihan, 168 buah data harian sebagai data validasi, dan 56 buah data harian sebagai data pengujian. Tabel 1 merupakan nilai MAPE setiap percobaan komposisi data yang dilakukan.

Tabel 1.

Nilai MAPE setiap percobaan Holts

\begin{tabular}{ccc}
\hline \hline & Pelatihan & Validasi \\
\hline 60\%:25\%:15\% & $1.247 \%$ & $1.020 \%$ \\
$\mathbf{7 0 \% : 2 0 \% : 1 0 \%}$ & $\mathbf{1 . 1 9 8 \%}$ & $\mathbf{0 . 7 0 3 \%}$ \\
\hline \hline
\end{tabular}




\begin{tabular}{lll}
$80 \%: 15 \%: 5 \%$ & $1.127 \%$ & $0.739 \%$ \\
\hline
\end{tabular}

Tabel 1 menunjukkan bahwa nilai MAPE terkecil adalah komposisi data 70\%:20\%:10\%. Maka dalam eksperimen ini, metode peramalan double exponential smoothing holt's menggunakan komposisi data $70 \%$ data pelatihan, $20 \%$ data validasi, dan $10 \%$ data pengujian. Banyaknya data pelatihan adalah 784 buah data harian dimulai dari tanggal 31 Desember 2012 hingga 31 Desember 2015, data validasi adalah 224 buah data harian dimulai dari 1 Januari 2016 hingga 18 November 2016, dan data pengujian sebanyak 112 buah data harian dimulai dari 21 November 2016 hingga 28 April 2017.

Diagram garis perbandingan antara data aktual (historis) dengan data hasil peramalan harga saham BBCA.JK menggunakan metode double exponential smoothing holt's dengan komposisi data $60 \%$ pelatihan, $25 \%$ validasi, dan $15 \%$ pengujian dapat dilihat pada Gambar 3 .

Diagram garis perbandingan antara data aktual (historis) dengan data hasil peramalan harga saham BBCA.JK menggunakan metode double exponential smoothing holt's dengan komposisi data $70 \%$ pelatihan, $20 \%$ validasi, dan $10 \%$ pengujian dapat dilihat pada Gambar 4.

Diagram garis perbandingan antara data aktual (historis) dengan data hasil peramalan harga saham BBCA.JK menggunakan metode double exponential smoothing holt's dengan komposisi data $80 \%$ pelatihan, $15 \%$ validasi, dan $5 \%$ pengujian dapat dilihat pada Gambar 5 .

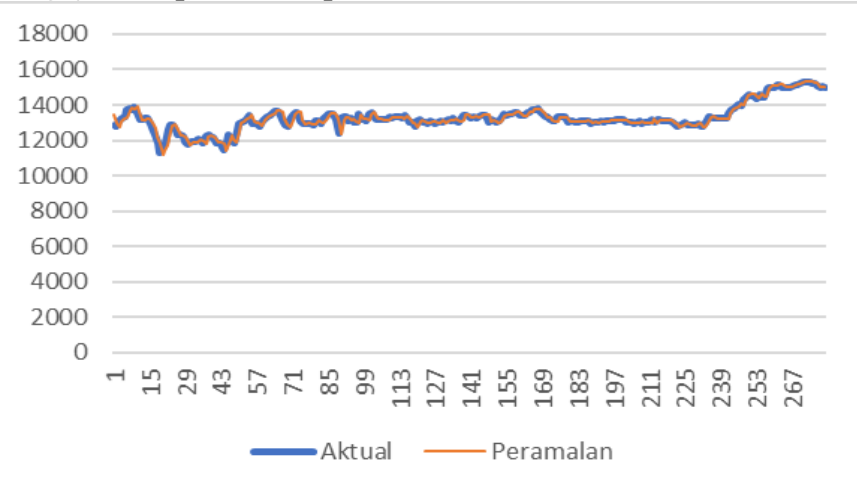

Gambar 3. Komposisi Data 60\% Pelatihan dan 25\% Validasi

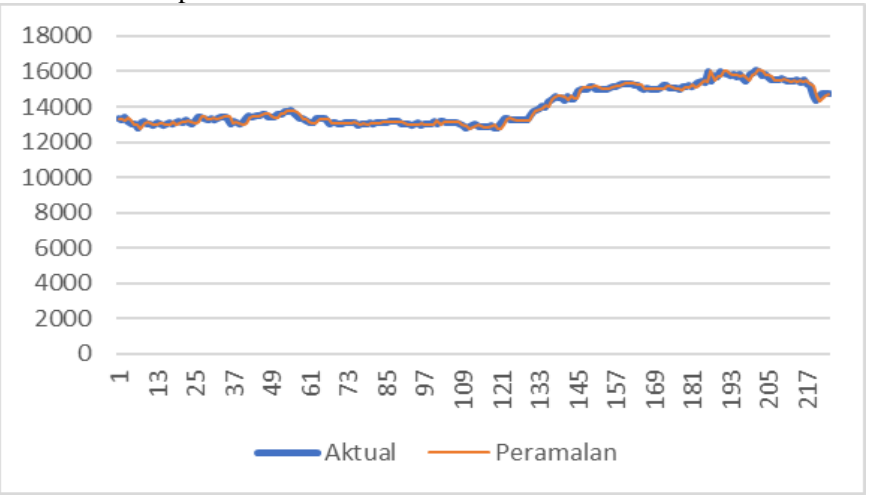

Gambar 4. Komposisi Data 70\% Pelatihan dan 20\% Validasi

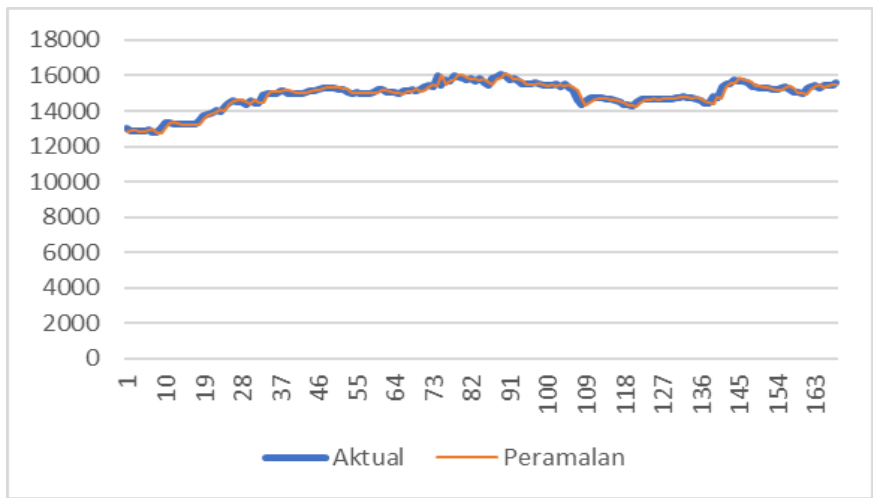

Gambar 5. Komposisi Data 80\% Pelatihan dan 15\% Validasi

Hasil dalam bentuk diagram batang dapat dilihat pada Gambar 6. Dari diagram pada Gambar 6, dapat diketahui bahwa komposisi data yang memiliki kesalahan MAPE yang terkecil adalah $70 \%$ data pelatihan, $20 \%$ data validasi dan $10 \%$ data pengujian.

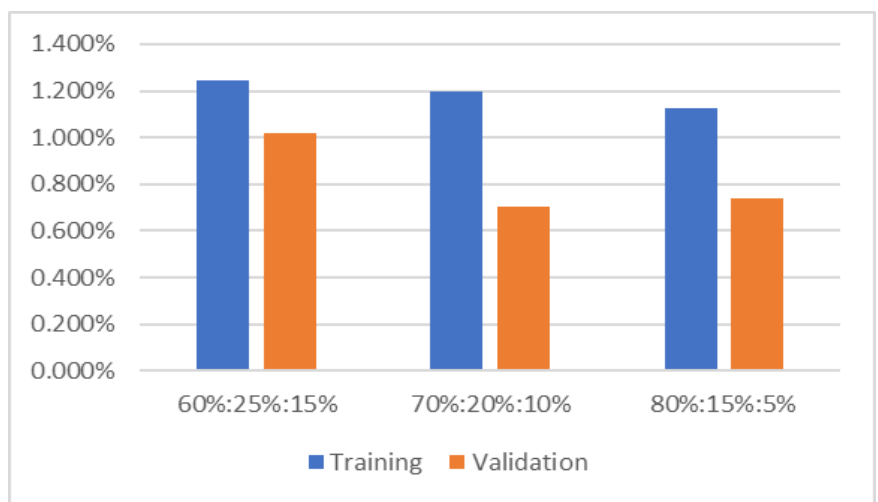

Gambar 6. Perbandingan kesalahan MAPE

\section{Pengujian model Peramalan}

Setelah melakukan proses pelatihan dan validasi dilakukan proses pengujian model peramalan. Masing-masing model yang diperoleh dari tahap pelatihan dilakukan validasi dan diambil yang terbaik dari hasil validasi. Kemudian model yang terbaik dikonfirmasi menggunakan data pengujian. Sehingga tahapan akhir pengujian model peramalan hanya untuk mengkonfirmasi model terbaik yang diperoleh dari pelatihan dan validasi memang benar-benar bagus. Tabel 2 merupakan nilai MAPE yang dihasilkan dari pengujian model.

Tabel 2.

Nilai MAPE Pengujian Model

\begin{tabular}{cc}
\hline \hline & Pengujian \\
\hline $70 \%: 20 \%: 10 \%$ & $0.823 \%$ \\
\hline \hline
\end{tabular}

Diagram garis perbandingan antara data aktual (historis) dengan data hasil peramalan harga saham BBCA.JK menggunakan metode double exponential smoothing holt's dengan komposisi data $70 \%$ pelatihan, $20 \%$ validasi, dan $10 \%$ pengujian dapat dilihat pada Gambar 7. 


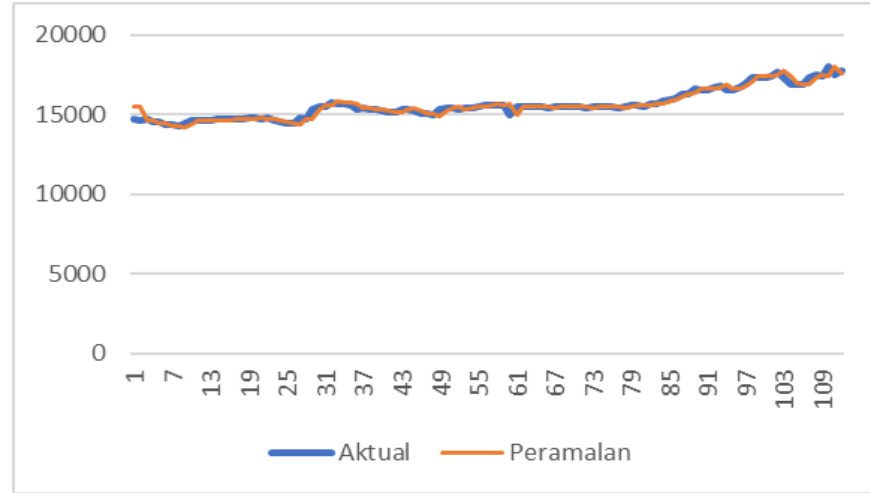

Gambar 7. Komposisi Data 70\% Pelatihan, 20\% Validasi dan 10\% Pengujian

\section{Hasil Pengujian Model}

Pembangunan model prediksi harga saham penutupan PT Bank Central Asia Tbk dengan metode holt's memiliki nilai $\alpha$ dan $\beta$, yaitu 0,9 dan 0,1 . Hal ini disebabkan oleh perubahan kedua data antar periode yang sangat kecil sehingga nilai level mendekati konstan dan nilai trend yang kecil. Tabel 3 menunjukkan contoh pengujian pada model prediksi harga saham penutupan PT BCA Tbk berdasarkan metode Holt's.

Tabel 3.

Contoh Pengujian Terhadap Model Prediksi Harga Saham Penutupan Metode Holt's

\begin{tabular}{rcc}
\hline \hline Date & Close Price & Prediksi \\
\hline $1 / 2 / 2017$ & 15500 & 15556 \\
$1 / 3 / 2017$ & 15775 & 15572 \\
$1 / 4 / 2017$ & 15700 & 15840 \\
$1 / 5 / 2017$ & 15675 & 15786 \\
$1 / 6 / 2017$ & 15600 & 15748 \\
$1 / 9 / 2017$ & 15350 & 15664 \\
$1 / 10 / 2017$ & 15400 & 15402 \\
$1 / 11 / 2017$ & 15300 & 15421 \\
$1 / 12 / 2017$ & 15325 & 15322 \\
$1 / 13 / 2017$ & 15275 & 15335 \\
$1 / 16 / 2017$ & 15175 & 15286 \\
$1 / 17 / 2017$ & 15175 & 15181 \\
$1 / 18 / 2017$ & 15300 & 15170 \\
$1 / 19 / 2017$ & 15375 & 15293 \\
$1 / 20 / 2017$ & 15250 & 15380 \\
$1 / 23 / 2017$ & 15050 & 15265 \\
$1 / 24 / 2017$ & 15050 & 15054 \\
$1 / 25 / 2017$ & 14950 & 15032 \\
$1 / 26 / 2017$ & 15300 & 14933 \\
$1 / 27 / 2017$ & 15400 & 15271 \\
$1 / 30 / 2017$ & 15450 & 15406 \\
$1 / 31 / 2017$ & 15300 & 15469 \\
$2 / 1 / 2017$ & 15425 & 15325 \\
$2 / 2 / 2017$ & 15450 & 15432 \\
$2 / 3 / 2017$ & 15475 & 15467 \\
$2 / 6 / 2017$ & 15600 & 15493 \\
$2 / 7 / 2017$ & 15625 & 15618 \\
$2 / 8 / 2017$ & 15600 & 15654 \\
\hline \hline
\end{tabular}

\section{KESIMPULAN}

Berdasarkan hasil penelitian pada eksperimen yang telah dilakukan, maka didapatkan kesimpulan sebagai berikut:
1. Dilihat dari aspek pemenuhan tujuan, dalam eksperimen ini telah berhasil didesain serta dibangun aplikasi berbasis website sebagai implementasi peramalan harga saham berbasis model double exponential smoothing holt's berdasarkan hasil analisis peramalan yang berasal dari model peramalan yang dilakukan dalam eksperimen ini.

2. Metode holt's bagus dalam mengevaluasi model secara keseluruhan untuk data time series.

3. Dalam eksperimen ini model peramalan terbaik diperoleh dari pembagian 3 tahun data pelatihan, 11 bulan data validasi, dan 5 bulan data pengujian, menghasilkan nilai MAPE sebesar $0.823 \%$.

4. Pada eksperimen ini, peramalan menggunakan metode holt's menghasilkan MAPE yang sangat baik yaitu sebesar $0.823 \%$. Hal ini menunjukkan bahwa metode time series double exponential smoothing holt's memiiki performa yang baik dan cocok untuk diterapkan dalam memprediksi harga saham pada PT Bank Central Asia Tbk.

\section{DAFTAR PUSTAKA}

Anoraga, Pengantar Pasar Modal Edisi Revisi. Jakarta: Rineka Cipta, 2001.

[2] M. Riadi, "Pengertian dan Jenis-Jenis Saham," 2012. [Online]. Available: http://www.kajianpustaka.com/2012/12/pengertian-danjenis-jenis-saham.html.

[3] M. Kiki, "Bagaimana Cara Berinvestasi dan Keuntungannya," 2017. .

[4] B. Afrianto, "Prediksi Pergerakan Harga Saham Menggunakan Back Propagation Neural Network," Simantec, vol. 3, p. 133, 2013.

[5] P. Yoga, "Saham 3 bank ini paling diincar investor," 2016. [Online]. Available: http://infobanknews.com/saham-3-bank-inipaling-diincar-investor/.

[6] A. Hartono, "Investasi Emas atau Saham atau Reksadana atau Property," $2017 . \quad$ [Online]. Available: http://mengelolakeuangan.com/investasi-emas-atau-saham-ataureksadana/.

[7] I. Hatimah, "Perbandingan Metode Double Moving Average dan Pemulusan Eksponensial Ganda dari Holt dalam Peramalan Harga Saham," EKSPONENSIAL, vol. 4, no. 1, 2013. 